\title{
Type 1 Diabetes and Intestinal Microbiota: How Geographic Differences Between Human Cohorts Can Influence Interpretation of Associations
}

\author{
Alexandria N Ardissone, Kaisa M Kemppainen and Eric W Triplett*
}

Department of Microbiology and Cell Science, Institute of Food and Agricultural Sciences, University of Florida, Gainesville, FL, USA

\begin{abstract}
Evidence is growing for a role of the intestinal microbiome in the development of type 1 diabetes (T1D) in humans. The composition of the microbiota is heavily influenced by environmental and developmental factors, making the identification of disease-specific microbial signatures difficult. This review summarizes the impact of geographic location, a major confounder of the intestinal microbiota, on the discovery and validation of T1D-microbiota associations as reported in published case-control studies. Few common taxonomic associations were observed across studies and geographic locations, possibly due to the large effect of environmental confounders. In the future, a focus on single geographic regions and integration of multi-omic data will help in identifying disease signatures and potential functional biomarkers of T1D.
\end{abstract}

Keywords: Type 1 diabetes; Microbiota; Geography; Confounder

Abbreviations: T1D: Type 1 Diabetes; IA: Islet Autoimmunity

\section{Introduction}

Type 1 diabetes (T1D) is an autoimmune disease characterized by the destruction of insulin-producing beta islet cells of the pancreas and the inability to properly regulate blood glucose levels. The incidence of T1D varies greatly by country [1] with the highest incidence occurring in Finland (62.5 cases per 100,000 persons per year) [2]. Although the exact etiologies of the disease are not fully understood, the interplay between genetic susceptibility, environmental triggers, and immune regulation are implied [3]. While genetics play a large role in disease susceptibility, T1D incidence is increasing globally at a rate that cannot be attributed to genetic shifts alone [4], thus providing support that environmental factors contribute to disease.

T1D is a complex, multifactorial disease believed to have different sequences of events leading to onset of disease [3]. In addition to genetic susceptibility, the development of islet autoantibodies (seroconversion) is a biomarker which precedes clinical onset of disease. These autoantibodies are reactive to insulin, the $65 \mathrm{kDa}$ form of glutamic acid decarboxylase, zinc transporter 8 , and insulinoma autoantigen 2 [3]. T1D risk varies depending on the pattern of autoantibody acquisition [5]. Also, a higher risk of T1D is conferred if autoantibodies appear early in life [6], and the etiology of childhood onset disease likely differs from that of adult onset [7]. Hence, not all cases of T1D or T1D autoimmunity will have the same environmental triggers.

The intestinal microbiota is thought to potentiate T1D autoimmunity by altering immune regulation, the presentation of antigens, or intestinal barrier function [8]. Numerous studies in rodent models provide mechanistic evidence that gut microbe-immune interactions appear to be crucial in establishing a balance of immune tolerance early in life garnering support for the role of the intestinal microbiota in T1D. In humans, microbiota affiliations with T1D have thus far been limited to a handful of longitudinal and cross-sectional case-control studies. The majority of published studies were conducted in pediatric populations with genetic predisposition for T1D from Europe or North America with a focus on microbial differences prior to the onset of Islet Autoimmunity (IA) or clinical diagnosis of T1D.

So far, studies conducted in geographically distinct populations lack common geographic findings. This is not surprising considering the diversity in T1D etiology and the multitude of environmental factors affecting the composition of the intestinal microbiota [9]. Therefore, the aim of this mini-review to compare these studies and their findings in the context of geographic differences.

\section{Geography in Human Microbiota Studies}

The gut microbiota is a naturally diverse environment that develops with age and is unique to each individual. While intrinsic factors, such as genetics, have some impact on gut microbial composition [10,11], many studies have shown that the external environment is the biggest driver of microbiota diversity [12]. Numerous factors influence microbial composition throughout life, including delivery mode, infant feeding (breastfeeding, formula feeding, and use of probiotics), use of antibiotics and other medications. Diet is considered one of the biggest confounders, with significant microbial changes being induced by even short-term changes in diet [13].

Although many factors can influence the microbiota, geographic location and age frequently explain the majority of microbial variation in microbiota studies [14]. Geographic location and age can be considered meta-confounders, that is broad variables that encompass numerous covariates that influence the microbiota allowing generalizations to be made about the population under investigation. Generally, it is not latitude and longitude nor age themselves that have a direct effect on microbiota, but rather that these variables are suggestive of genetic background, environmental, cultural, and dietary habits or developmental and nutritional confounders.

${ }^{*}$ Corresponding author: Eric W. Triplett, Department of Microbiology and Cell Science, Institute of Food and Agricultural Sciences, University of Florida, 1355 Museum Rd., P.O. Box 110700, Gainesville, FL, 32611-0700, USA, Tel: 1-352-3921906; E-mail: ewt@ufl.edu

Received: July 31, 2017; Accepted: August 16, 2017; Published: August 21, 2017

Citation: Ardissone AN, Kemppainen KM, Triplett EW (2017) Type 1 Diabetes and Intestinal Microbiota: How Geographic Differences Between Human Cohorts Can Influence Interpretation of Associations. Diabetes Case Rep 2: 128. doi: $10.4172 / 2572-5629.1000128$

Copyright: (c) 2017 Ardissone AN, et al. This is an open-access article distributed under the terms of the Creative Commons Attribution License, which permits unrestricted use, distribution, and reproduction in any medium, provided the original author and source are credited. 
Microbiota variation between geographically distinct populations has been consistently observed [14-20]. These findings are not surprising, as several of the studies compared extremely different populations (e.g., Malawians to Amerindians to the USA [14]; Italian to Burkina Faso [15]; USA to Bangladesh [19]), and they primarily attribute 'geographic' differences to differences in diet and a westernlifestyle. For example, in the study comparing the microbiota of children in Italy and Burkina Faso, the children in Italy were completely weaned from a milk-based diet by 1 year of age, but this occurred closer to 2 years of age in children in Burkina Faso [15]. Thus, the researchers concluded that the microbiota of children in Burkina Faso had a delayed maturation compared to Italian children and attributed this to the difference in age of weaning rather than age itself specifically or even diet or geography [15]. Such studies rely on geography to accumulate the effects of numerous factors on the microbiota in order to capture a maximal amount of variation between different populations. However, this gross simplification overlooks the microbial heterogeneity within a given population.

More constrained studies comparing the microbiota of children from different countries with a western-lifestyle also report geographic differences $[17,20]$, drawing attention to possible effects of genetic, cultural, and true geographic influences on the microbiota. Whether microbial variation is attributed directly to surrounding host environment or some other underlying factor, restricting geography in study design is expected to be useful in mitigating the effects of confounding variables in microbiota studies [9].

\section{Microbiota in T1D Studies and Geography}

There is a lack of consensus on taxonomic associations from studies of IA or T1D and the microbiota. This is not surprising given the extent to which environmental factors can influence microbiota in relation to the small effects of disease. Here results are compared from five longitudinal and three cross-sectional case-control studies describing T1D- or IA-associated microbial signatures and emphasize geographic differences with the expectation that underlying environmental variables may be attributed to differing results and discuss important considerations for future studies.

\section{Bacteroidetes}

A general trend of increased abundance of members of the phylum Bacteroidetes, specifically Bacteroides dorei in Turku, Finland [21], and a decrease in the abundance of Firmicutes prior to seroconversion has been observed in the Type 1 Diabetes Prediction and Prevention (DIPP) study [21,22]. A different cohort of older Finnish children also observed increased Bacteroides abundance in children with islet autoantibodies [23]. In the BABYDIET cohort study in Germany, subjects with a high abundance of Bacteroides at 6 months of age were at an increased risk of early autoantibody development, but this trend was not particularly prevalent in subjects included in the study [24]. Similar differences were not seen in a longitudinal case-control comparison in DIABIMMUNE, a study of Finnish and Estonian children [25], or in a cross-sectional study conducted in Denver, Colorado [26], possibly due to differences in study protocol, sample size, and geographic location (Table 1). Specifically, Finnish children enrolled in the DIABIMMUNE study were from Espoo, Finland whereas those with increased $B$. dorei enrolled in DIPP were from Turku, Finland. A separate geographic comparison of subjects in DIABIMMUNE reported a higher relative abundance of Bacteroidetes in Finnish samples compared to neighboring Russian Karelia [27]. Kemppainen et al. in 2015 observed an increased abundance of Bacteroides in children at risk for T1D in
Finland and Colorado compared to Georgia, Washington, Germany and Sweden [20]. This would suggest that while Finnish children tend to harbor a greater relative abundance of Bacteroides compared to other nations, the composition of this phyla varies within Finland. Furthermore, this conjecture is supported by a study of a small subset of children enrolled in DIPP from Oulu and Tampere, Finland that did not observe an increase of $B$. dorei but did observe an imbalance of other Bacteroides genera compared to controls [28]. This observation was further correlated with a bacteriophage, which was hypothesized to have a modulatory effect on Bacteroides populations [28].

So far, studies limited to one clinical site tend to report taxonomic differences between cases and controls [21,22,26,29], while studies with subjects from multiple geographically distinct sites do not report such associations [30]. The BABYDIET study, which enrolled children with a first-degree relative with T1D, did not see any taxonomic or functional differences in children prior to seroconversion [30]. The authors hypothesized that this may be due to underlying differences caused by early life environmental exposures [30]. This hypothesis is supported by the fact that these children came from multiple cities across Germany, and thus environmental confounders likely influenced the ability to detect taxa-specific associations with disease. However, they did observe that the microbial interaction networks of children that went on to develop T1D were substantially altered from controls, supporting the notion that a perturbation in microbiota precedes disease [30].

\section{Diversity}

The microbial diversity of pre-autoimmune children is not well defined, with some studies reporting clear decreases in diversity prior to seroconversion $[22,23]$ while other studies see no difference in diversity measures between those that seroconvert and healthy controls [25,26,30]. Meanwhile, a decrease in microbial diversity after seroconversion but prior to T1D onset was reported [25]. Thus, microbial diversity may be more indicative of events leading to T1D, but not IA, but fewer studies have evaluated the former. It is important to note that all studies reported alpha diversity metrics, general measurements of species richness and/or evenness and are not informative of phylogenetic relationships within a microbial community. These studies used either Chaol or Shannon diversity metrics (Table 1), which are not comparable. In addition, alpha diversity calculations are highly influenced by how read counts were processed, thus drawing into question the comparability of reported diversity findings across studies. Therefore, differences in diversity measures between T1D-microbiota studies are likely driven by technical variation in addition to geographical location. Of particular importance, the studies that reported an association of diversity with IA or T1D [22,25], respectively, were underpowered (4 case subjects in both studies) compared to other studies considered. The fact that the two larger studies $[25,30]$ did not find a difference in diversity of pre-autoimmune subjects is not surprising as an increase in sample size often leads to an increase in data variance making it more difficult to identify disease-specific differences. Since microbial diversity metrics differ by geographical location $[14,15,19,31]$, it may be helpful to focus on a single location for future autoimmune microbiota studies.

\section{Promise of Metagenomic and Integrative Studies}

Seroconversion and later T1D onset in Finnish and Estonian children was characterized by metagenomic changes with an increase in the abundance of genes involved in sugar transport and a decrease in genes involved in the biosynthesis of amino acids [25]. Similar 
Citation: Ardissone AN, Kemppainen KM, Triplett EW (2017) Type 1 Diabetes and Intestinal Microbiota: How Geographic Differences Between Human Cohorts Can Influence Interpretation of Associations. Diabetes Case Rep 2: 128. doi: 10.4172/2572-5629.1000128

Page 3 of 5

\begin{tabular}{|c|c|c|c|c|c|c|c|c|c|c|}
\hline \multirow[b]{2}{*}{ Study } & \multirow[b]{2}{*}{$\operatorname{Ref}^{*}$} & \multicolumn{4}{|c|}{ Demographic variables } & \multicolumn{2}{|c|}{ Technical variables } & \multicolumn{3}{|c|}{ Findings } \\
\hline & & Age & \# Subjects & $\begin{array}{c}\text { Geographic } \\
\text { location }\end{array}$ & Outcome & $\begin{array}{c}\text { Sequencing } \\
\text { platform and } \\
\text { variable region }\end{array}$ & $\begin{array}{c}\text { Coverage } \\
\text { (reads/ } \\
\text { sample) }\end{array}$ & $\begin{array}{l}\text { Microbial } \\
\text { diversity }\end{array}$ & $\begin{array}{l}\text { Taxonomic } \\
\text { differences }\end{array}$ & $\begin{array}{c}\text { Were } \\
\text { confounders } \\
\text { considered? }\end{array}$ \\
\hline \multirow{3}{*}{ DIPP } & Giongo [22] & $\begin{array}{c}4 \\
\text { months } \\
-3 \\
\text { years }\end{array}$ & 8 & $\begin{array}{l}\text { Turku, } \\
\text { Finland }\end{array}$ & IA & $\begin{array}{c}454 \\
\text { pyrosequencing; } \\
\text { V3 }\end{array}$ & 15,709 & $\begin{array}{c}\text { SDI - decreased } \\
\text { prior to IA and at } \\
\text { seroconversion }\end{array}$ & $\begin{array}{c}\text { Increased } \\
\text { Bacteroidetes } \\
\text { and decreased } \\
\text { Firmicutes prior } \\
\text { to IA and at } \\
\text { seroconversion }\end{array}$ & $\begin{array}{l}\text { No, but cases and } \\
\text { controls matched } \\
\text { for age and HLA } \\
\text { genotype }\end{array}$ \\
\hline & Brown [29] & $\begin{array}{c}4 \\
\text { months } \\
-3 \\
\text { years }\end{array}$ & 8 & $\begin{array}{l}\text { Turku, } \\
\text { Finland }\end{array}$ & IA & $\begin{array}{l}\text { Illumina GAllx; } \\
\text { WGS }\end{array}$ & NA & Not reported & $\begin{array}{c}\text { Decrease } \\
\text { in butyrate } \\
\text { producing } \\
\text { bacteria and } \\
\text { mucin degrading } \\
\text { bacteria in cases }\end{array}$ & $\begin{array}{l}\text { No, but cases } \\
\text { and controls were } \\
\text { matched for age } \\
\text { and HLA genotype }\end{array}$ \\
\hline & $\begin{array}{c}\text { Davis- } \\
\text { Richardson [21] }\end{array}$ & $\begin{array}{c}4 \\
\text { months } \\
-2.2 \\
\text { years }\end{array}$ & 76 & $\begin{array}{l}\text { Turku, } \\
\text { Finland }\end{array}$ & IA & $\begin{array}{l}\text { Illumina HiSeq; } \\
\text { V4 }\end{array}$ & 357,581 & Not reported & $\begin{array}{c}\text { Higher } \\
\text { abundance of } \\
\text { Bacteroides dorei } \\
\text { in cases prior to } \\
\text { seroconversion }\end{array}$ & $\begin{array}{l}\text { Yes - age; mode } \\
\text { of delivery; } \\
\text { duration of } \\
\text { exclusive BF and } \\
\text { total BF; antibiotics } \\
\text { use }\end{array}$ \\
\hline \multirow[b]{2}{*}{ BABYDIET } & Endesfelder ${ }^{[30]}$ & $\begin{array}{c}\text { 3-36 } \\
\text { months }\end{array}$ & 44 & Germany & IA & $\begin{array}{l}\text { Illumina GAllx; } \\
\text { V4 }\end{array}$ & $\begin{array}{l}\text { Not } \\
\text { reported }\end{array}$ & $\begin{array}{l}\text { Choa1 and SDI } \\
\text { - no differences }\end{array}$ & $\begin{array}{l}\text { No difference } \\
\text { between cases } \\
\text { and controls }\end{array}$ & $\begin{array}{c}\text { Yes - age; BF; } \\
\text { duration of BF; } \\
\text { introduction of } \\
\text { solid food; delivery } \\
\text { mode }\end{array}$ \\
\hline & Endesfelder [24] & $\begin{array}{c}6 \\
\text { months }\end{array}$ & 44 & Germany & IA & $\begin{array}{l}\text { Illumina GAllx; } \\
\text { V4 }\end{array}$ & $\begin{array}{l}\text { Not } \\
\text { reported }\end{array}$ & Not reported & $\begin{array}{l}\text { Subjects high in } \\
\text { Bacteroides at } \\
6 \text { months had } \\
\text { an increased } \\
\text { risk of early } \\
\text { autoantibody } \\
\text { development. }\end{array}$ & $\begin{array}{c}\text { Yes - age; BF; } \\
\text { duration of BF; } \\
\text { introduction of } \\
\text { solid food; delivery } \\
\text { mode }\end{array}$ \\
\hline DIABIMMUNE & Kostic ${ }^{[25]}$ & $\begin{array}{c}\text { Birth - } 3 \\
\text { years }\end{array}$ & 33 & $\begin{array}{l}\text { Finland, } \\
\text { Estonia }\end{array}$ & IA; T1D & $\begin{array}{l}\text { Illumina MiSeq; } \\
\text { V4 }\end{array}$ & 65,076 & $\begin{array}{c}\text { Choa1 - } \\
\text { decreased prior } \\
\text { to T1D }\end{array}$ & $\begin{array}{c}\text { Decreased } \\
\text { abundance } \\
\text { of Blautia, } \\
\text { Rickenellaceae, } \\
\text { Ruminococcus } \\
\text { and } \\
\text { Streptococcus } \\
\text { spp.; increase in } \\
\text { Lachnospiraceae } \\
\text { and } \\
\text { Veillonellaceae } \\
\text { before onset of } \\
\text { T1D }\end{array}$ & $\begin{array}{l}\text { Yes - gender; } \\
\text { HLA; country; } \\
\text { delivery mode; } \\
\text { antibiotic use; BF; } \\
\text { introduction to } \\
\text { solid food, eggs, } \\
\text { soy, rye, barley, } \\
\text { millet, buckwheat, }\end{array}$ \\
\hline \multicolumn{2}{|c|}{ Alkanani ${ }^{[26]}$} & $\begin{array}{l}2-45 \\
\text { years }\end{array}$ & 111 & $\begin{array}{l}\text { Denver, } \\
\text { Colorado, } \\
\text { USA, }\end{array}$ & IA; T1D & $\begin{array}{l}\text { Illumina MiSeq; } \\
\text { V4 }\end{array}$ & 131,000 & $\begin{array}{l}\text { SDI and } \\
\text { richness - no } \\
\text { difference } \\
\text { between IA } \\
\text { positive subjects } \\
\text { and healthy } \\
\text { controls with an } \\
\text { IA-FDRs. }\end{array}$ & $\begin{array}{c}\text { Increased } \\
\text { abundance } \\
\text { of some } \\
\text { Bacteroidetes } \\
\text { (Prevotellaceae, } \\
\text { RC9 gut } \\
\text { group) and } \\
\text { Catenibacterium } \\
\text { in IA cases } \\
\text { compared to } \\
\text { healthy controls } \\
\text { with an IA-FDR; } \\
\text { decrease in } \\
\text { unclassified } \\
\text { Bacteroidetes in } \\
\text { IA positive cases. }\end{array}$ & $\begin{array}{l}\text { Yes - sex; age; } \\
\text { HLA genotype }\end{array}$ \\
\hline \multicolumn{2}{|c|}{ de Goffau ${ }^{[23]}$} & $\begin{array}{l}4-14 \\
\text { years }\end{array}$ & 36 & Finland & IA & $\begin{array}{c}454 \\
\text { pyrosequencing; } \\
\text { V1-3 }\end{array}$ & 12,830 & $\begin{array}{l}\text { Chao1 and } \\
\text { OUT count - } \\
\text { decresed in } \\
\text { cases in the } \\
\text { older TRIGR } \\
\text { subjects }\end{array}$ & $\begin{array}{c}\text { Increased } \\
\text { abundance of } \\
\text { Bacteroidetes, } \\
\text { Bacteroides; } \\
\text { decreased } \\
\text { abundance } \\
\text { of Roseburia, } \\
\text { Eubacterium, } \\
\text { butyrate and } \\
\text { lactate producing } \\
\text { bacteria in cases. }\end{array}$ & $\begin{array}{l}\text { Yes - age; sex; } \\
\text { HLA genotype; } \\
\text { time of exposure to } \\
\text { infant formula, type } \\
\text { of infant formula; } \\
\text { delivery mode; } \\
\text { duration of BF }\end{array}$ \\
\hline
\end{tabular}




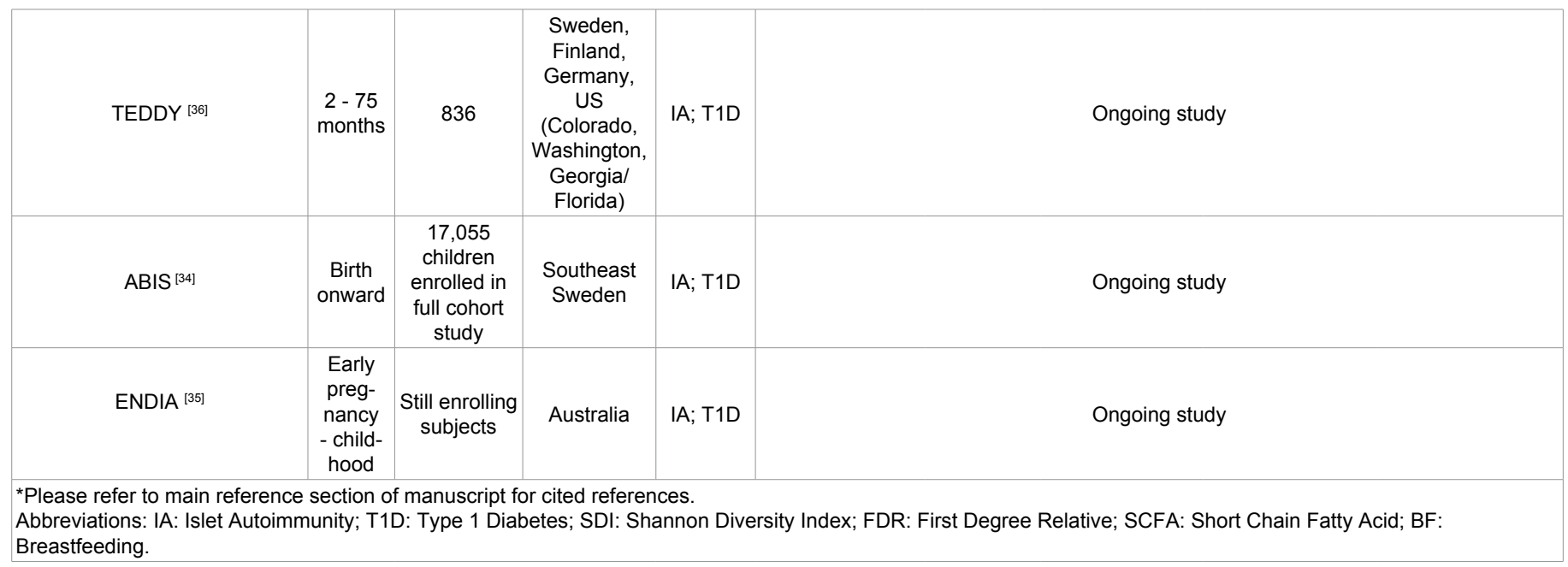

Table 1: Human studies investigating role of the gut microbiota in development of IA or T1D. Comparison of demographic and technical variables, and findings of microbial diversity and taxonomic differences.

metagenomic changes were observed in an earlier study even though the two studies did not identify the same taxonomic differences [29]. The metabolomic potential of the microbiota is similar across individuals and geographic locations, even when taxonomic composition differs $[25,32,33]$ and therefore metagenomic studies may be the key to finding common microbial signatures in IA and T1D studies around the world, even if taxonomic differences are not reproducible.

Despite not having a similar taxonomic composition, children from Germany and Finland developing islet autoantibodies have a reduction in the number of butyrate-producing bacteria before seroconversion, and after the appearance of autoantibodies [23,24,29]. They also have an increased abundance of Bacteroides and a decrease in the abundance of mucin degrading bacteria, such as Akkermansia [21-24,29]. Increased risk of early islet autoantibody development was found in German children with decreased abundance of genes involved with butyrate production via acetate-co-fermentation pathway, and early introduction to solid foods, suggesting that early feeding practices may play a role in the establishment of a pre-autoimmune microbiota [24]. This, coupled with an increase in the abundance of genes involved in sulfur metabolism seen in Finnish children [29] has helped put forth an improved hypothesis for the role of Bacteroides and Akkermansia in butyrate production and gut health [24]. These findings show that through incorporation of multiple data types within microbiota analyses, it is possible to find common disease-specific trends when combining geographically distinct populations.

\section{Comparability of Studies and Considerations for Future Studies}

Most publications that examined microbiota differences prior to IA or T1D have stemmed from three major prospective cohort studies: DIPP, BABYDIET, and DIABIMMUNE. These cohorts are well suited to address microbiota confounders, as several demographic variables were recorded and samples were subjected and processed under the same protocols, limiting the likelihood of reporting associations due to technical variation. This consistency also makes such cohort studies valuable as additional samples may serve in future validation experiments. Integration of omics data with such carefully collected data on environmental exposures have produced hypotheses about the role of the microbiota in T1D $[23-25,29]$ that can be further validated with intervention studies and/or studies in rodent models. Such studies will be important for validating current findings and developing potential therapeutics or intervention strategies for T1D.

Results from upcoming cohort studies, including All Babies in SouthEast Sweden (ABIS) [34], the Environmental Determinants of Islet Autoimmunity (ENDIA) [35], and The Environmental Determinants of Diabetes in the Young (TEDDY) study [36] (Table 1) will be valuable for further elucidating the role of microbiota in IA and T1D, as well as conducting meta-analyses to identify any potential global disease-microbiota associations. The ongoing TEDDY study, with subjects enrolled from three countries in the EU and three states in the USA, will be especially suited for providing a direct look at the impact of geographic location in the context of IA and T1D.

\section{Discussion and Conclusion}

Disease-specific microbiota signatures are dwarfed by the variability derived from other environmental factors. Therefore, it's important to account, or control, for these confounders in studies of disease-microbiota interactions. As a variable, geographic location can be used to capture a multitude of less well-defined environmental factors and social practices that more directly influence microbial composition. Metagenomic studies may be better suited to identify common disease-specific signatures across geographically distinct populations as microbial functions are shared among different taxa. Also, a proper meta-analysis of available T1D-microbiota datasets would reduce technical variation arising from different methods of processing sequencing reads, and help comparability of studies. A more thorough approach is required to fully understand the complex interactions between host, microbiota, and the environment as they relate to autoimmunity for T1D and its different etiologies.

\section{Conflict of Interest}

The authors declare no conflict of interest in the submission of this manuscript

\section{References}

1. Karvonen M, Viik-Kajander M, Moltchanova E, Libman I, LaPorte R, et al. (2000) Incidence of childhood type 1 diabetes worldwide. Diabetes Mondiale (DiaMond) Project Group. Diabetes Care 23: 1516-1526.

2. Harjutsalo V, Sund R, Knip M, Groop PH (2013) Incidence of type 1 diabetes in Finland. JAMA 310: 427-428.

3. Atkinson MA, Eisenbarth GS, Michels AW (2014) Type 1 diabetes. Lancet 383 $69-82$ 
Citation: Ardissone AN, Kemppainen KM, Triplett EW (2017) Type 1 Diabetes and Intestinal Microbiota: How Geographic Differences Between Human Cohorts Can Influence Interpretation of Associations. Diabetes Case Rep 2: 128. doi: 10.4172/2572-5629.1000128

4. DIAMOND Project Group (2006) Incidence and trends of childhood Type 1 diabetes worldwide 1990-1999. Diabet Med 23: 857-866.

5. Achenbach P, Warncke K, Reiter J, Naserke HE, Williams AJ, et al. (2004) Stratification of type 1 diabetes risk on the basis of islet autoantibody characteristics. Diabetes 53: 384-392.

6. Hummel S, Ziegler AG (2011) Early determinants of type 1 diabetes: Experience from the BABYDIAB and BABYDIET studies. Am J Clin Nutr 94: 1821S-1823S.

7. Sabbah E, Savola K, Ebeling T, Kulmala P, Vähäsalo P, et al. (2000) Genetic, autoimmune, and clinical characteristics of childhood and adultonset type 1 diabetes. Diabetes Care 23:1326-3132.

8. Vaarala O (2013) Human intestinal microbiota and type 1 diabetes. Curr Diab Rep 13: 601-607.

9. Davis-Richardson AG, Triplett EW (2015) A model for the role of gut bacteria in the development of autoimmunity for type 1 diabetes. Diabetologia 58: 1386-1393.

10. Khachatryan ZA, Ktsoyan ZA, Manukyan GP, Kelly D, Ghazaryan KA, et al. (2008) Predominant role of host genetics in controlling the composition of gut microbiota. PLoS One 3: e3064.

11. Spor A, Koren O, Ley R (2011) Unraveling the effects of the environment and host genotype on the gut microbiome. Nat Rev Microbiol 9: 279-290.

12. Turnbaugh PJ, Hamady M, Yatsunenko T, Cantarel BL, Duncan A, et al. (2009) A core gut microbiome in obese and lean twins. Nature 457: 480-484.

13. Albenberg LG, Wu GD (2014) Diet and the intestinal Microbiome: Association, functions, and implications for health and disease. Gastroenterol 146: 1564-1572.

14. Yatsunenko T, Rey FE, Manary MJ, Trehan I, Dominguez-Bello MG, et al. (2012) Human gut microbiome viewed across age and geography. Nature 486: 222-227.

15. De Filippo C, Cavalieri D, Di Paola M, Ramazzotti M, Poullet JB, et al. (2010) Impact of diet in shaping gut microbiota revealed by a comparative study in children from Europe and rural Africa. Proc Natl Acad Sci 107: 14691-1466.

16. Echarri PP, Graciá CM, Berruezo GR, Vives I, Ballesta M, et al. (2011) Assessment of intestinal microbiota of full-term breast-fed infants from two different geographical locations. Early Hum Dev 87: 511-513.

17. Fallani M, Young D, Scott J, Norin E, Amarri S, et al. (2010) Intestinal microbiota of 6-week-old infants across Europe: Geographic influence beyond delivery mode, breast-feeding, and antibiotics. J Pediatr Gastroenterol Nutr 51: 77-84.

18. Grześkowiak $Ł$, Grönlund MM, Beckmann C, Salminen S, Von Berg A, et al (2012) The impact of perinatal probiotic intervention on gut microbiota: doubleblind placebo-controlled trials in Finland and Germany. Anaerobe 18: 7-13.

19. Lin A, Bik EM, Costello EK, Dethlefsen L, Haque R, et al. (2013) Distinct dista gut microbiome diversity and composition in healthy children from Bangladesh and the United States. PLoS One 8: e53838.

20. Kemppainen KM, Ardissone AN, Davis-Richardson AG, Fagen JR, Gano KA, et al. (2015) Early childhood gut microbiomes show strong geographic differences among subjects at high risk for type 1 diabetes. Diabetes Care 38: 329-332.

21. Davis-Richardson AG, Ardissone AN, Dias R, Simell V, Kemppainen K, et al. (2014) Bacteroides dorei dominates gut microbiome prior to autoimmunity in Finnish children at high risk for type 1 diabetes. Front Microbiol 5: 678.
22. Giongo A, Gano KA, Crabb DB, Murkherjee N, Novelo LL, et al. (2011) Toward defining the autoimmune microbiome for type 1 diabetes. ISME J5: 82-91.

23. De Goffau MC, Luopajärvi K, Knip M, Ilonen J, Ruohtula T, et al. (2013) Fecal microbiota composition differs between children with $\beta$-cell autoimmunity and those without. Diabetes 62: 1238-1244.

24. Endesfelder D, Engel M, Davis-Richardson AG, Ardissone AN Achenbach P, et al. (2016) Towards a functional hypothesis relating anti-islet cell autoimmunity to the dietary impact on microbial communities and butyrate production. Microbiome 4: 17.

25. Kostic AD, Gevers D, Siljander H, Vatanen T, Hyötyläinen T, et al. (2015) The dynamics of the human infant gut microbiome in development and in progression toward type 1 diabetes. Cell Host Microbe 17: 260-273.

26. Alkanani AK, Hara N, Gottlieb PA, Ir D, Robertson CE, et al. (2015) Alterations in intestinal microbiota correlate with susceptibility to type 1 diabetes. Diabetes 64: $3510-3520$.

27. Vatanen T, Kostin AD, d'Hennezel E, Siljander H, Franzosa EA, et al. (2016) Variation in microbiome LPS immunogenicity contributes to autoimmunity in humans. Cell 165: 1551

28. Cinek O, Kramna L, Lin J, Oikarinen S, Kolarova K, et al. (2016) Imbalance of bacteriome profiles within the Finnish Diabetes Prediction and Prevention study: Parallel use of $16 \mathrm{~S}$ profiling and virome sequencing in stool samples from children with islet autoimmunity and matched controls. Pediatr Diabetes: 12468.

29. Brown CT, Davis-Richardson AG, Giongo A, Gano KA, Crabb DB, et al. (2011) Gut microbiome metagenomics analysis suggests a functional model for the development of autoimmunity for type 1 diabetes. PLoS One 6: e25792.

30. Endesfelder D, Castell W, Ardissone A, Davis-Richardson AG, Achenbach $P$, et al. (2014) Compromised gut microbiota networks in children with antiislet cell autoimmunity. Diabetes 63: 2006-2014

31. Lee S, Sung J, Lee J, Ko G (2011) Comparison of the gut microbiotas of healthy adult twins living in South Korea and the United States. Appl Environ Microbiol 77: 7433-7437.

32. The Human Microbiome Project Consortium (2012) Structure, function and diversity of the healthy human microbiome. Nature 486: 207-214.

33. Qin J, LiR, Raes J, Arumugam M, BurgdorfKS, etal. (2010)A human gut microbia gene catalogue established by metagenomic sequencing. Nature 464: 59-65.

34. Berzina L, Shtauvere-Brameus A, Ludvigsson J, Sanjeevi CB (2002) Newborn screening for high risk human leukocyte antigen markers associated with insulin dependent diabetes mellitus: The ABIS Study. Ann N Y Acad Sci 958: 312-316.

35. Penno MA, Couper JJ, Craig ME, Colman PG, Rawlinson WD, et al. (2013) Environmental determinants of islet autoimmunity (ENDIA): A pregnancy to early life cohort study in children at-risk of type 1 diabetes. BMC Pediatr 13: 124 .

36. Lee H-SS, Burkhardt BR, McLeod W, Smith S, Eberhard C, et al. (2014 Biomarker discovery study design for type 1 diabetes in The Environmenta Determinants of Diabetes in the Young (TEDDY) study. Diabetes Metab Res Rev 30: 424-434. 